\title{
The application of interactive multimedia CD-ROM technology to wildland fire safety training ${ }^{1}$
}

\author{
by R.W. Thorburn², A. MacMillan ${ }^{3}$ and M.E. Alexander ${ }^{4}$
}

Interactive multimedia technology has been utilized in the development of a CD-ROM based wildland fire safety training course, Wildland Fire - Safety on the Fireline. Interactive multimedia technology allows delivery of training to a large number of students on a consistent basis. In addition, cost savings can be achieved through reduced learning time, reduced travel, minimal use of instructors, and most of all, through retention of knowledge as a result of using multimedia. The course, Wildland Fire - Safety on the Fireline, was developed and reviewed by a national team of specialists in wildland fire behavior and wildland fire safety with the intent of reducing and/or eliminating injuries and fatalities associated with the suppression of wildland fires. Wildland Fire - Safety on the Fireline focuses on due diligence, situational awareness, entrapment survival, health, equipment, and hazards encountered when working on the fireline. Each of the four sections comprising the course is followed by a board game test in preparation for a final test that is tracked by the computer.

Key words: Canada, computer applications, fire behavior, fire entrapment avoidance, firefighter fatalities, firefighter physiology, fire suppression, fire survival, personal protective equipment, risk management, safe work practices, situational awareness, wildfire case studies, wildland firefighting, wildland-urban interface.

La technologie interactive multimédia a été utilisée pour développer un cours de formation sur la sécurité lors des feux de forêt reposant sur un disque compact, Wildland Fire - Safety on the Fireline. La technologie interactive multimédia permet de donner une formation à un grand nombre d'étudiants sur une base constante. De plus, des économies au niveau des coûts peuvent être réalisées grâce à la réduction du temps de formation, la réduction du nombre de déplacement, l'utilisation réduite d'instructeurs, et surtout grâce à une mémorisation des connaissances suite à l'utilisation du multimédia. Le cours, Wildland Fire - Safety on the Fireline, a été élaboré et révisé par une équipe nationale de spécialistes en comportement des feux de forêt et en sécurité en matière de feux de forêt dans le but de réduire ou encore d'éliminer les blessures et les pertes de vie associées à la suppression des feux de forêt. Wildland Fire - Safety on the Fireline porte principalement sur les mesures à prendre, la sensibilisation face au contexte, la survie en cas d'encerclement, l'état de santé, l'équipement, et les dangers qui surviennent lors de travaux sur la ligne de feu. Chacune des quatre sections incluses dans le cours est suivie d'un test de simulation programmé qui mène à l'examen final qui est suivi par l'ordinateur.

Mots-clés : Canada, applications informatiques, comportement du feu, évitement de l'encerclement par le feu, pertes de vie chez les pompiers, physiologie du pompier, suppression du feu, survie au feu, équipement de protection individuelle, gestion du risque, méthodes sécuritaires de travail, sensibilisation face au contexte, études de cas de feux de forêt, suppression des feux de forêt, interface forêtmilieu urbain

Until firefighters have a passion for safety like Canadians have a passion for hockey our work is not done.

Jandt (1998)

\section{Introduction}

There have been very few fire behavior-related fatalities resulting from wildland firefighting in Canada in comparison to the United States (who have probably ten times

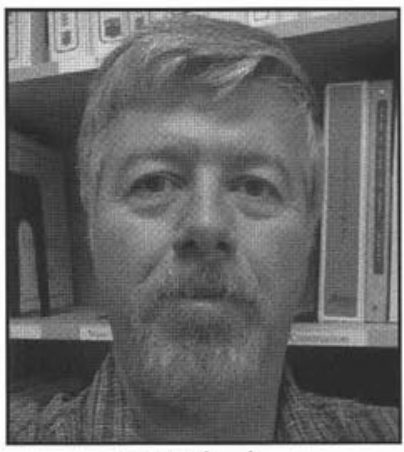

R.W. Thorburn

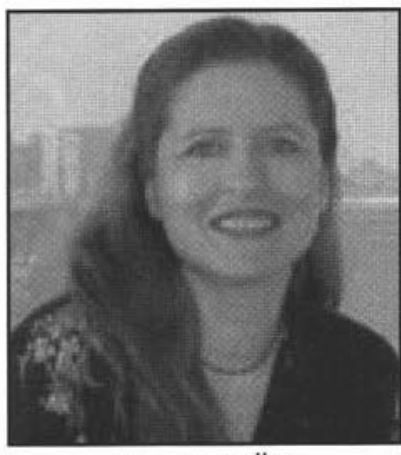

A. MacMillan

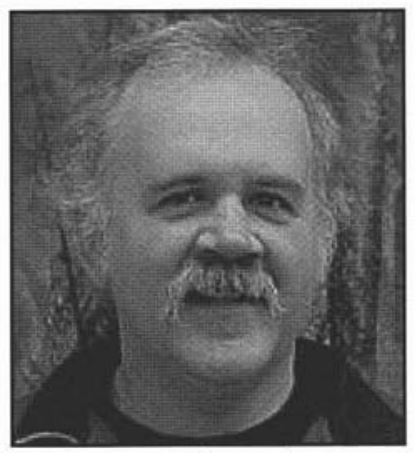

M.E. Alexander
${ }^{1}$ Based on a paper presented at the 4 th International Wildland Fire Safety Summit sponsored by the International Association of Wildland Fire, Edmonton, Alberta, October 10-12, 2000.

${ }^{2}$ Team Leader, Wildland Fire Management Training Program, Environmental Training Centre, Alberta Environment, 1176 Switzer Drive, Hinton, Alberta T7V 1V3. E-mail: Rob.Thorburn@gov.ab.ca

${ }^{3}$ President, Christie Communications, \#1002 10611-98 Avenue, Edmonton, Alberta T5K 2P7. E-mail: lex@christie.ab.ca

${ }^{4}$ Senior Fire Behavior Research Officer, Northern Forestry Centre, Canadian Forest Service, 5320-122 Street, Edmonton, lberta T6H 3S5. E-mail: malexand@nrcan.gc.ca or more wildfires than Canada), where there have been at least 414 reported deaths in the past 91 years (Fig. 1). Consequently, burn-overs and entrapments on wildland fires in Canada are a relatively rare occurrence. However, in spite of what appears to be a near spotless safety record, there have been some documented and untold numbers of unreported "near misses" or "close calls" (e.g., BCFS Safety Review Team 1994, Bachop 1998). 
Firefighter Fatalities Associated with Wildfire Entrapments \& Burnovers - USA

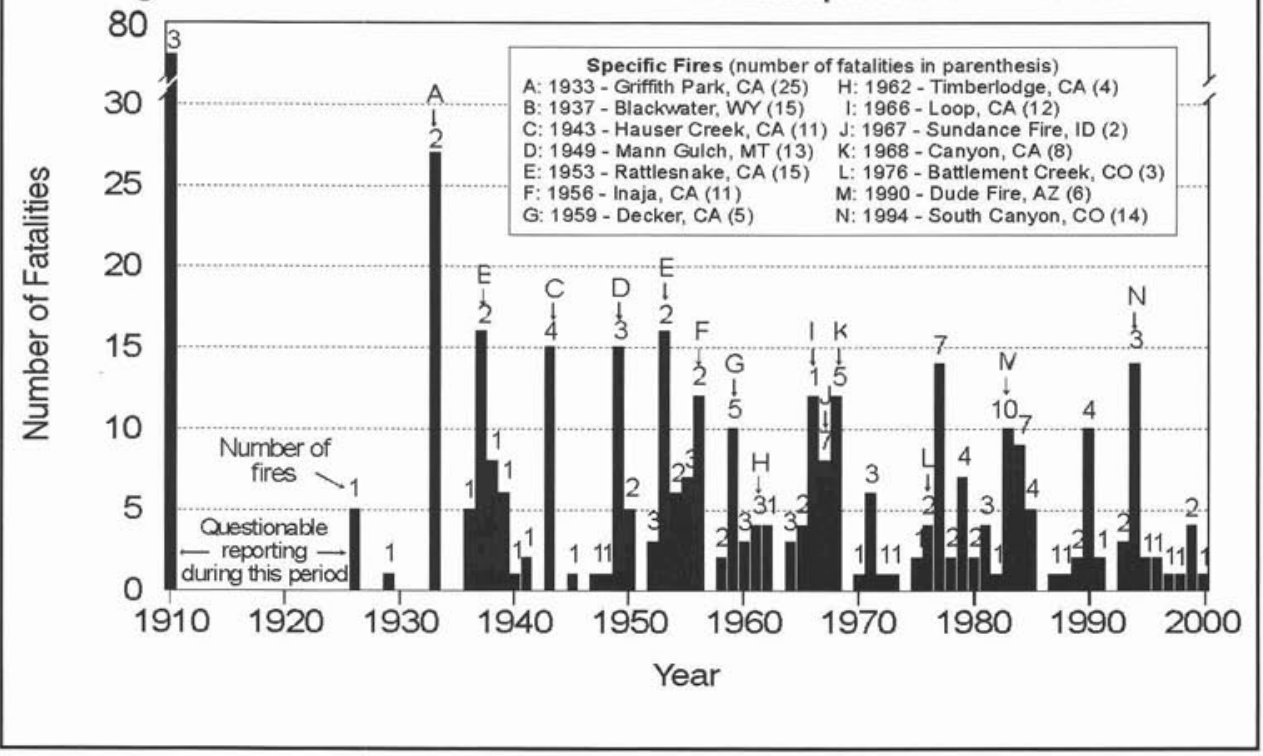

Figure 1. Reported firefighter fatalities associated with wildland fire entrapments and burnovers in the United States, 1910-2000 (from data in NWCG Safety and Health Working Team 1997, 2000 and Mangan 1999). Some historically significant fatality fires have been highlighted.
It would be quite easy to become complacent when dealing with firefighter safety based on documented statistics. Some senior managers and policy makers alike may perceive fireline safety to be a non-issue. Nevertheless, there are a number of reasons to be vigilant over safety issues that apply not only to Canada but the United States as well. Some of these issues are:

- reduction in senior fire personnel in recent years;

- mounting wildland-urban interface fire problems;

- more frequent episodes of critical fire weather, perhaps due to climate change;

- "implied" pressure to keep area burned in commercial forest areas to a minimum;

- possible escalation of the "gung-ho" approach to firefighting largely due to romanticizing by the media and fire management agencies themselves and other aspects of the wildfire suppression culture (Beaver 1998, Hartley and Langlois 1998);

- fuel build-up in short-interval fire regime fuel types and an increase in fuel continuity in the southern boreal forest; and

- difficulty in accessing standardized fire safety training.

While there are some very good safety training materials available within the wildland fire community such as "Standards for Survival" in 1987, "Look Up, Look Down, Look Around" in 1992, and "Lessons Learned: Fatality Fire Case Studies" in 1998 (NWCG 2000), most of this material is oriented to traditional classroom training approaches (i.e., lecture-style teacher-student interaction).

Given that the current generation of wildland firefighters has strongly developed skills in the audio-visual area, an interactive multimedia training CD-ROM approach is a natural and more current way to approach the issue of fire safety training and education for wildland firefighters. What is multimedia? Multimedia is a carefully orchestrated interaction of video, audio, text, graphics, slides, and animation. When users are enabled to control the pace and direction of information presented with a computer thorough these media, the program is known as "interactive multimedia."

\section{About the New Course Wildland Fire - Safety on the Fireline}

The Environmental Training Centre in concert with a multimedia producer (Christie Communications), has undertaken a number of multimedia training projects in the area of wildland fire over the last several years (ETC and NWCG 1997, ETC 1998, Hirsch 1998). As a result, Alberta's Environmental Training Centre received the mandate in late 1998 from the Canadian Interagency Forest Fire Centre (CIFFC) Board of Directors, and in turn the CIFFC National Training Working Group, to develop an interactive multimedia CD-ROM for the delivery of wildland firefighter safety training (Thorburn 1998). With the assistance of a national content team ${ }^{5}$ comprised of wildland fire behavior and fire safety specialists, the CD-ROM Wildland Fire - Safety on the Fireline (ETC 2000) was completed in June 2000 following alpha and beta testing and is now available for general distribution (Fig. 2).

\section{What is the Course About?}

The ultimate goal of the Wildland Fire - Safety on the Fireline $\mathrm{CD}-\mathrm{ROM}$ training course is to teach anyone who is involved in fighting wildfires how to work safely and productively on the fireline (Budd et al. 1996), regardless of their position in the wildland fire community. To teach this critical information, this multimedia program uses the interaction of video, audio, text, graphics, photos, and animation. Wildland Fire - Safety on the Fireline contains 72 video clips, over 250 audio clips

\footnotetext{
${ }^{5}$ The team members were R.W. Thorburn, who served as the project coordinator, M.E. Alexander, D. Campbell (Department of Environment and Resource Management, Prince Albert, Saskatchewan), and J. McLevin (Land and Forest Service, Lac La Biche, Alberta).
} 


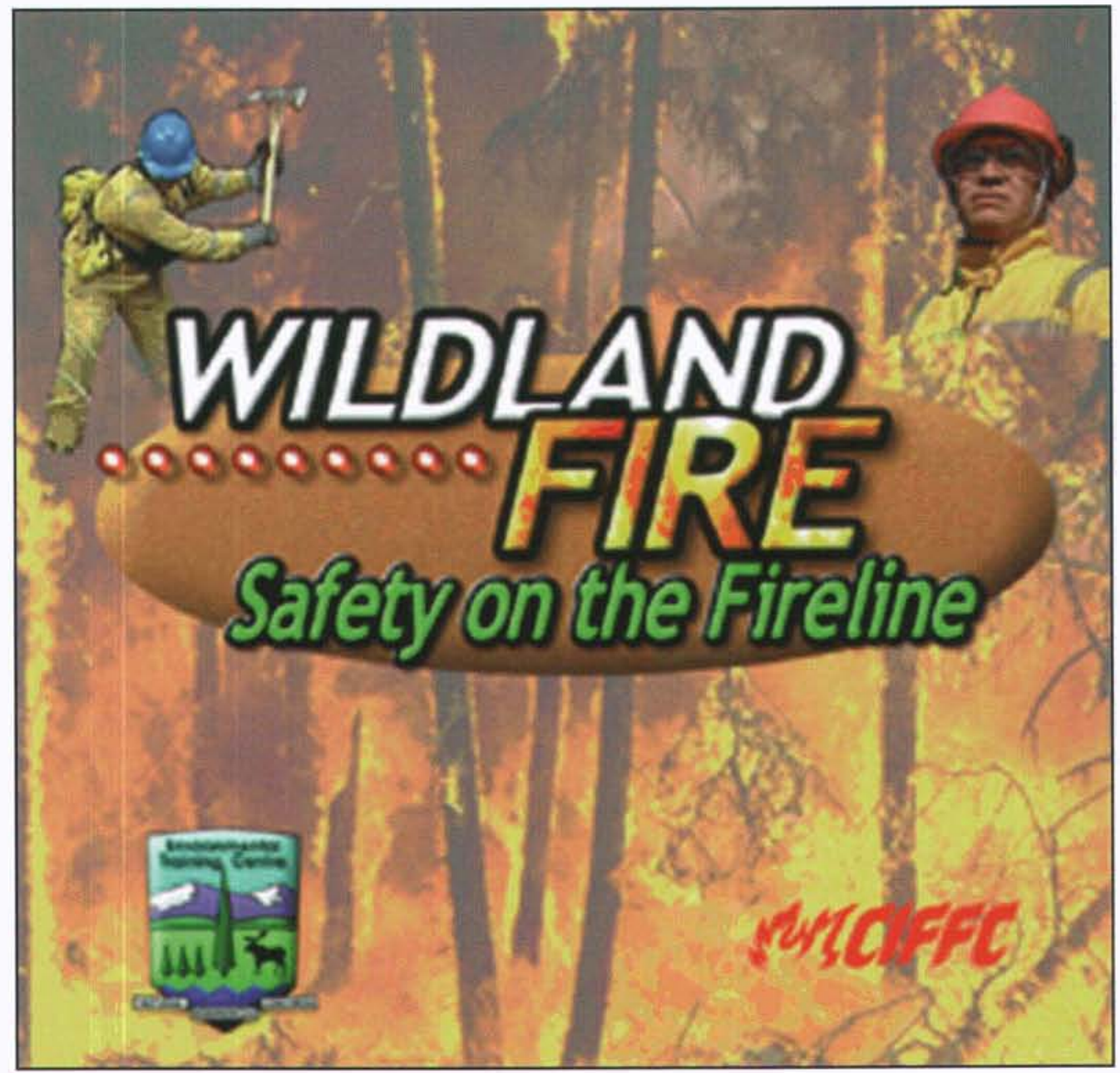

Figure 2. Cover plate for the Wildland Fire - Safety on the Fireline CD-ROM. and some 500 graphics/photos. In the tools menu, the program includes on-line help, a course map, a glossary, SI-to-imperial unit conversion calculator, references, and an electronic index.

Wildland Fire - Safety on the Fireline was developed and reviewed by subject matter specialists in wildland fire behavior and wildland fire safety. This quality expertise can now be delivered to a large number of students on a consistent basis, using the CD-ROM interactive training approach. Wildland -Safety on the Fireline is primarily aimed at the on-theground wildland firefighter, although anyone involved in fighting wildland fires will find it of value. In addition, cost savings in training can be achieved through reduced learning time, reduced travel, minimal use of instructors, and most of all, retention of knowledge. However, the bottom line benefit of this training program is to reduce and/or eliminate injures and fatalities associated with the suppression of wildland fires.

\section{What is in the Course?}

Wildland Fire - Safety on the Fireline is divided into four main sections, each containing a "board game" section test to help learners review material and ensure they are ready to proceed (Fig. 3).
Section 1: Introduction - the Introduction Section has two activities. The Course Introduction Activity includes information on help/controls, acknowledgements, learner objectives, a course map, and prerequisites to the course. The Safety Introduction Activity teaches areas such as safety responsibilities, due diligence, leadership, adaptiveness, personal ability, reinforcement, continued training, and a risk management process patterned after Cook's (1995) fire environment size-up model.

Section 2: Entrapment - the Entrapment Section contains three activities. In these activities, learners also get to try scenariobased interactions that give them an opportunity to apply the theory. Entrapment Avoidance teaches situational awareness, the 10 standard fire orders (McArdle 1957, Moore 1959, Morse and Monesmith 1987), the 18 situations that shout "watch out," tactical watchouts, downhill checklist items, lookout requirements, fireline communication, escape routes, safety zones, and the common denominators of fire behavior on fatal and near-fatal wildland fires (Wilson 1977). In some cases, the existing fire safety guidelines and job aids were slightly altered. One example was to suggest that the original standard fire order "Fight fire aggressively, but provide for SAFETY first" (McArdle 1957, Moore 1959) should perhaps read 


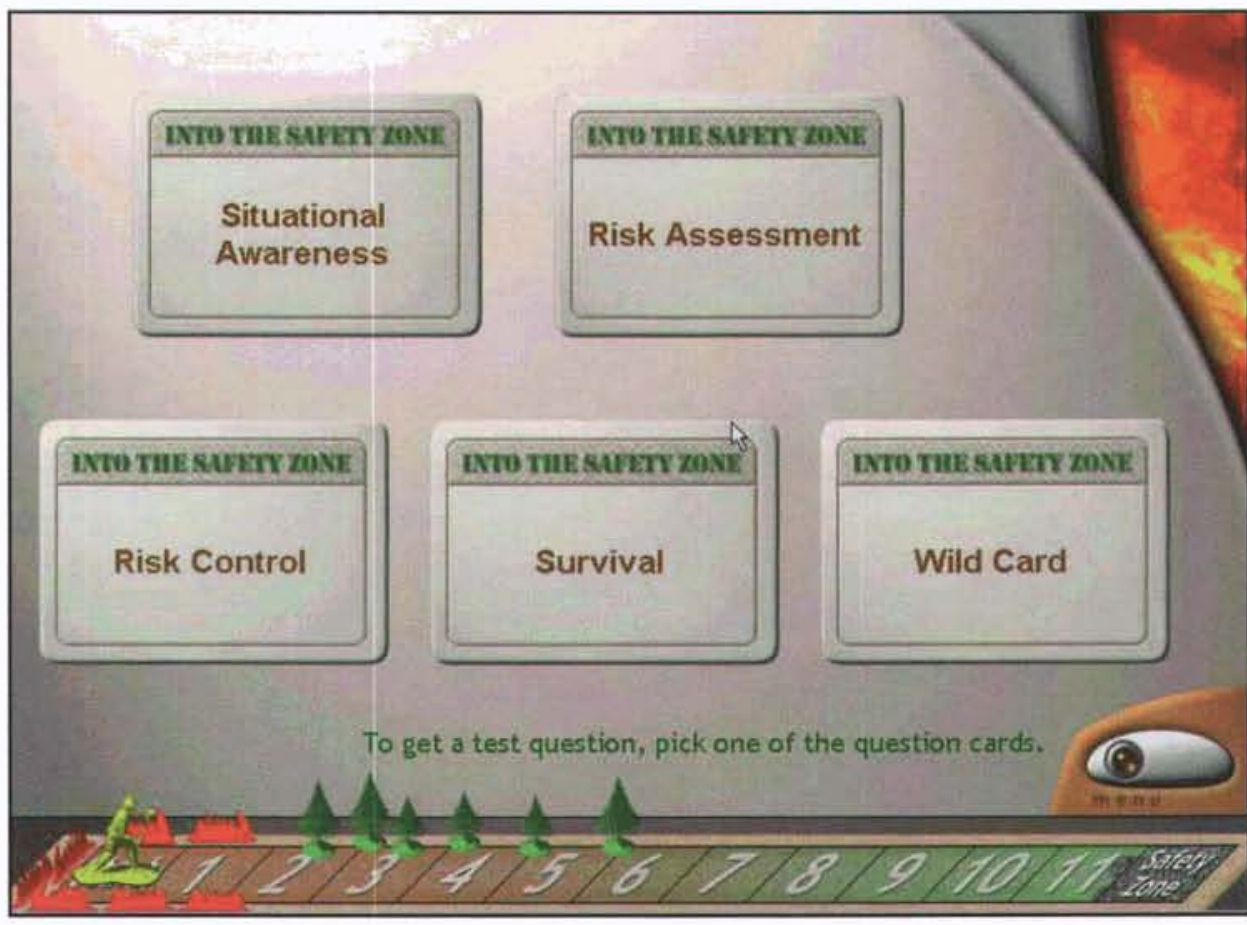

Figure 3. Sample window from the Wildland Fire - Safety on the Fireline CD-ROM illustrating a board game.
"Fight fire safety and intelligently." Another was to add an "A" (for Anchor point) to Gleason's (1991) LCES (Lookouts, Communication, Escape routes, Safety zones) fireline safety system so that it became LACES; plus, it has the added advantage of being a more mnemonic device.

The Indicators of Potential Fire Behavior Hazards component of this section is all about identifying the fuel, topographical, weather, and fire behavior indicators. This activity contains a "flash card" exercise that lets learners practice identification. Entrapment Survival describes heat radiation hazards, methods of preventing exposure, escaping an entrapment situation, and the procedures for vehicle and heavy equipment entrapment.

Section 3: On-the-Job - The three activities in this section are Your Body, Equipment, and Working with Others. The activity Your Body focuses on the effects of heat stress and fatigue, prevention methods, and basic treatment. In a "try-it-out" exercise, learners can experiment with firefighter fluid levels to see the results. The Equipment Activity describes the key considerations for personal protective equipment (PPE), including working with and caring for hand tools. In the Working with Others Activity, learners are taught the safety intelligence flow on the fireline, the importance of safety briefings (tailgate meetings), employee and supervisor safety responsibilities, and the incident reporting process (Fig. 4).

Section 4: On the Line - this section contains the final three activities. The Fireline Concerns Activity describes the safety procedures for working on the fireline. It includes hazards such as getting lost, falling rocks and/or logs, snags, heavy equipment, thunderstorms, fixed wing and rotary wing aircraft, retardant drops, and nighttime firefighting. Each learner is asked to pick out the snags by using his/her cursor as a flashlight in this activity's exercise. The Urban Interface Activity provides an overview of the pitfalls of fighting wildland fire near or around burning structures. This activity includes wildland firefighter responsibilities, urban/wildland watchouts, high voltage powerline concerns, and safety considerations for dealing with vehicle fires. A "try-it-out" exercise asks learners to pick the wildland/urban interface watchout situations from a graphic. In the Course Summary Activity, learners are given the opportunity to apply knowledge from all sections of the course in four interactive wildland fire case studies. These include the 1994 South Canyon Fire in Colorado (Butler et al. 1998, Maclean 1999) and three fatality fires that are used in national fire behavior training courses, Advanced Wildland Fire Behavior and Wildland Fire Behavior Specialist, involving a logger on a slash fire in coastal British Columbia in 1991, a rural volunteer firefighter on a wind-driven grass fire in southern Saskatchewan in 1993, and a rappattack crew member on a forest fire in north-central Alberta in 1995 (Alexander 1998).

Once learners have successfully completed these sections, they are given a final test (Fig. 5). Scores on all tests are recorded by a performance tracking system, which can be used by course administrators for certification purposes. It takes learners six to eight hours to complete the course; however, learners can take the course in shorter time duration, using the modular tracking system.

\section{What Are the System Requirements?}

The course can be run on a stand-alone computer or over a network. All computers, workstations, local computers, etc. where a course will be run should have:

- Pentium 166 or better with Windows 95, 98, or NT;

- a minimum of $32 \mathrm{MB}$ RAM and $100 \mathrm{MB}$ of free hard drive space (4 MB actually required for software);

- colour SVGA monitor set for $800 \times 600,16$ bit colour and $4 \mathrm{MB}$ video memory;

- 16 bit sound card (SoundBlaster); 

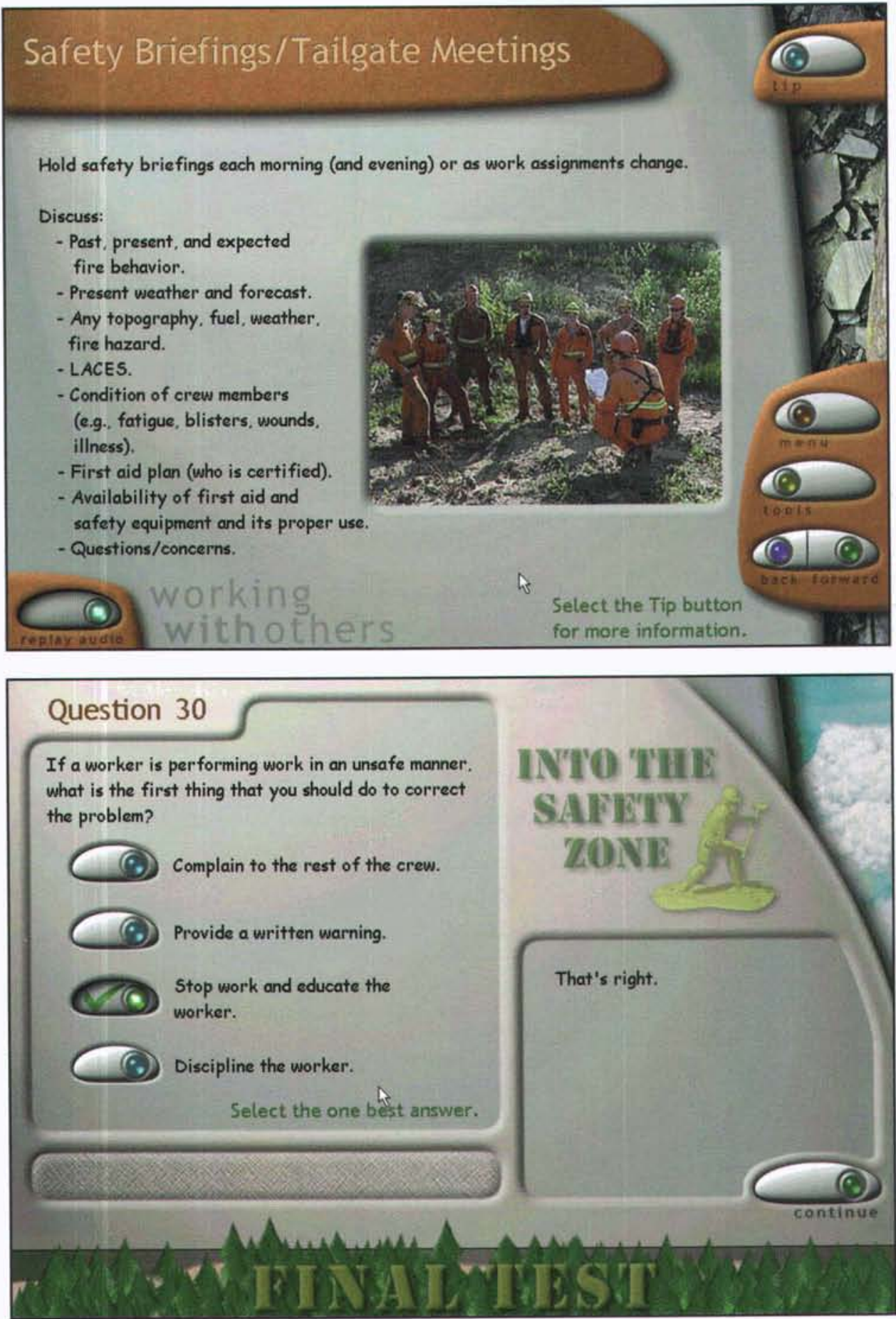

Figure 4. Sample window from the Wildland Fire - Safety on the Fire line $\mathrm{CD}-\mathrm{ROM}$ illustrating a user interface.

Figure 5. Sample window from the Wildland Fire - Safety on the Fireline CD-ROM illustrating a final test question.

- a $16 \mathrm{X}$ or better CD-ROM and its driver(s) (on every workstation); and

- mouse.

\section{Why Use Interactive Multimedia in Wildland Fire Safety Training?}

The following are the perceived advantages of using interactive multimedia technologies in wildland fire training courses like Wildland Fire - Safety on the Fireline (adapted from Miller 1990):
Take it any time you want - by using computer-based training (CBT), one can make use of low productivity time. All employees have periods of downtime. They have to wait for materials to arrive, or they finish the job an hour before the end of the day. Now, using CBT, they can turn lost time into productive time.

Take it anywhere you want - CBT can be delivered on computers at any location. There is no more travelling to a training centre. Employees can even take these courses at home! Student's inputs, selections and performance can also be tracked for certification purposes (Fig. 6). 


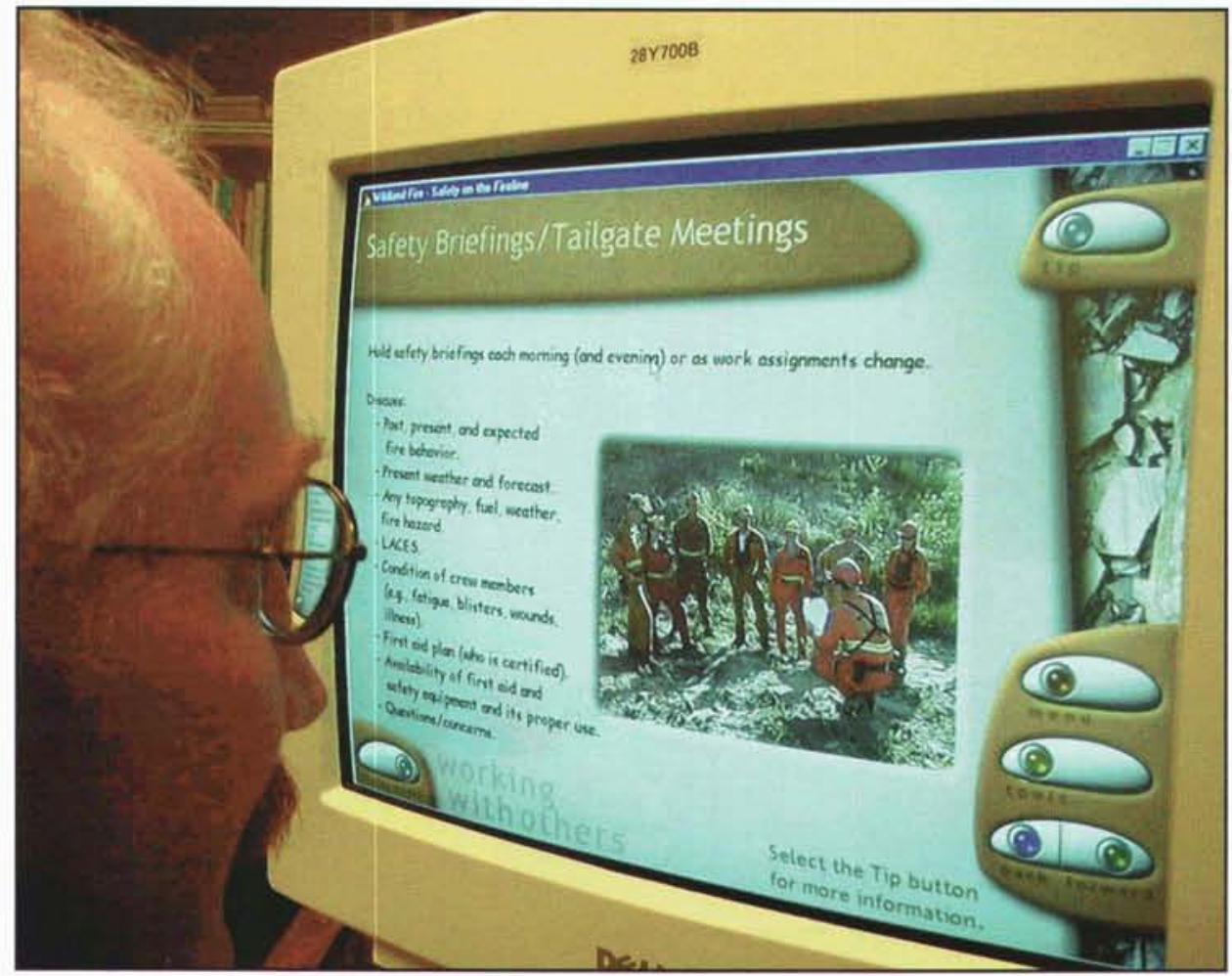

Figure 6. Computer-based wildland fire-fighter training in progress.
Reduction in learning time - CBT is up to four times more efficient than traditional training methods. That means that a traditional two-day training course can be delivered in as little as four hours. Since the largest cost in providing training to employees is their time away from the job, the savings can be enormous.

Educational consistency - a CBT course always provides the same content, day after day. When using multimedia, training is consistent. There are no bad days for the instructor and the content does not vary from class to class. High-quality expertise can be delivered to a large number of students.

Refresher training - time required to take refresher training can be significantly reduced since the program provides learners with control over their own learning path and depth. Job-aid component - because CBT can remain at the worksite, even certified employees can return to the course, select a small section from a course menu or index, and get the information they need to do a particular job. The courseware, in this way, does double duty as an on-line job aid.

Learner retention - complex theory is easy to teach. Knowledge is ensured through remedial feedback, practice and testing.

Quality training - Training employees to do the job right reduces waste, increases productivity, and prevents incidents and accidents.

\section{On the Future of Computer-based Wildland Fire and Forestry Training}

The computer has been gaining a steady foothold in the business of training in general over the last few years. In 1997, $80 \%$ of training was delivered by instructors (Trainersoft Corp. 2000). It is expected that by the year 2001 , over $50 \%$ of all training will be delivered by computers (Trainersoft Corp. 2000).

The Environmental Training Centre has been riding the wave of technological advancement in computer-based training for many years now (Thorburn 1990) and is currently starting out to develop a fifth interactive multimedia training CD-ROM. Its content will address the subject of the Canadian Forest Fire Weather Index System, a major module of the Canadian Forest Fire Danger Rating System (Stocks et al. 1989).

Interactive multimedia technology is suited not only to wildland fire management training but has the potential for many applications in other sectors of forestry and forest products as well. This has been demonstrated in the past by work done by Christie Communications (2000) on lumber grading and Vicom Multimedia (1992) on stand tending just to mention two such accomplishments.

\section{References}

Alexander, M.E. 1998. A wildland fire behavior researcher's perspective of firefighter safety in Canada. In Proceedings Canada/US Wildland Fire Safety Summit. p. 37. International Association of Wildland Fire, Fairfield, Washington.

Bachop, S. 1998. Provincial safety review team - successes and improvements. In Proceedings Canada/US Wildland Fire Safety Summit. pp. 59-64. International Association of Wildland Fire, Fairfield, Washington.

Beaver, A. 1998. Communication and firefighter safety - mixed messages. In Proceedings Canada/US Wildland Fire Safety Summit. pp. 45-51. International Association of Wildland Fire, Fairfield, Washington.

BCFS Safety Review Team. 1994. Safety review team report - a summary of the 1994 fire season. British Columbia Forest Service (BCFS). 12 p. 
Budd, G., J. Brotherhood, L. Hendrie, P. Cheney and M. Dawson. 1996. Safe and productive bushfire fighting with hand tools. Australian Government Publishing Service, Canberra, Australian Capital Territory. 34 p.

Butler, B.W., R.A. Bartlette, L.S. Bradshaw, J.D. Cohen, P.L. Andrews, T. Putnam and R.J. Mangan. 1998. Fire behavior associated with the 1994 South Canyon Fire on Storm King Mountain, Colorado. USDA Forest Service, Rocky Mountain Research Station, Fort Collins, Colorado. Research Paper RMRS-RP-9. 82 p. [see also: http://www.fs.fed.us/rm/pubs/rmrs rp9.html]

Christie Communications. 2000. Making the grade - lumber grading multimedia theory training. Version 2.0. Alberta Forest Products Association, Edmonton, Alberta, and Northern Lakes College, Slave Lake, Alberta. CD-ROM.

Cook, J. 1995. Fire environment size-up: human limitations vs. superhuman expectations. Wildfire 4(4): 49-53.

ETC. 1998. Principles of fire behavior. Environmental Training Centre (ETC), Hinton, Alberta. CD-ROM. [to order see: http://www.ubcpress.ubc.ca]

ETC. 2000. Wildland fire-safety on the fireline. Environmental Training Centre (ETC), Hinton, Alberta and Canadian Interagency Forest Fire Centre, National Training Working Group, Winnipeg, Manitoba. CD-ROM. [to order see: http://www.ubcpress.ubc.ca]

ETC and NWCG. 1997. Intermediate wildland fire behavior, S-290. Environmental Training Centre (ETC), Hinton, Alberta, and National Wildfire Coordinating Group (NWCG), Boise, Idaho. National Fire Equipment System Publication NFES 1592. CD-ROM. [to order see: http://www.blm.gov/fna/gbk/index.htm]

Gleason, P. 1991. LCES - a key to safety in the wildland fire environment. Fire Manage. Notes 52(4):9.

Hartley, B. and W. Langlois. 1998. Don't blame the goaltender the whole team is responsible for fireline safety. In Proceedings Canada/US Wildland Fire Safety Summit. p. 9. International Association of Wildland Fire, Fairfield. Washington.

Hirsch, K.G. 1998. Canadian Forest Fire Behavior Prediction (FBP) System: interactive training and reference. Canadian Forest Service, Northern Forestry Centre, and Alberta Environmental Protection, Forest Protection Division, Edmonton, Alberta. CD-ROM. [to order see: http://www.ubcpress.ubc.ca]

Jandt, D. 1998. A passion for safety - the Alaska Firefighter Safety and Health Committee. In Proceedings Canada/US Wildland Fire Safety Summit. pp. 65-66. International Association of Wildland Fire, Fairfield, Washington.

McArdle, R.E. 1957. Standard fire fighting orders. Fire Control Notes 18(4): 151 .
Maclean, J.N. 1999. Fire on the mountain: the true story of the South Canyon Fire. William Morrow and Company, Inc., New York, New York. 275 p.

Mangan, R.J. 1999. Wildland fire fatalities in the United States: 1990-1998. USDA Forest Service, Missoula Technology and Development Center, Missoula, Montana. Technical Report 9951-2808MTDC. 14 p.

Miller, R.L. 1990. Learning benefits of interactive technologies. The Videodisc Monitor 1990(Feb.): 15, 17

Moore, W.R. 1959. Training in the ten standard fire fighting orders. Fire Control Notes 20(3): 58-60.

Morse, G.A. and J.L. Monesmith. 1987. Firefighter safety: a new national emphasis. Fire Management Notes 48(4): 3-5.

NWCG. 2000. NWCG National Fire Equipment System catalogue part 2: publications. National Wildlfire Coordinating Group (NWCG), Boise, Idaho. National Fire Equipment System Publication NFES 3362. $114 \mathrm{p}$.

NWCG Safety and Health Working Team. 1997. Historical wildland firefighter fatalities 1910-1996. 2nd Edition. National Wildfire Coordinating Group (NWCG), Boise, Idaho. National Fire Equipment System Publication NFES 1849. 38 p.

NWCG Safety and Health Working Team. 2000. Safety gram. National Wildfire Coordinating Group (NWCG), Boise, Idaho. [see: http://www.nwcg.gov/teams/shwt/safgram00.pdf]

Stocks, B.J., B.D. Lawson, M.E. Alexander, C.E. Van Wagner, R.S. McAlpine, T.J. Lynham and D.E. Dubé. 1989. The Canadian Forest Fire Danger Rating System: an overview. For. Chron. 65(6): 450-457.

Thorburn, R.W. 1990. Videodisc/microcomputer technology in wildland fire training. In The Art and Science of Fire Management (M.E. Alexander and G.F. Bisgrove, tech. coords.). pp. 100-101. Information Report NOR-X-309, Forestry Canada, Northern Forestry Centre, Edmonton, Alberta.

Thorburn, R.W. 1998. Interactive multimedia training CD-ROM project: wildland fire safety. In Proceedings Canada/US Wildland Fire Safety Summit. pp. 57-58. International Association of Wildland Fire, Fairfield, Washington.

Trainersoft Corp. 2000. Multimedia authoring program, tutorial introduction. Trainersoft.com Corporation, Cary, North Carolina. CD-ROM. Vicom Multimedia. 1992. Manual stand tending. Alberta Environment, Alberta Land and Forest Service, Edmonton, Alberta, and Environmental Training Centre, Hinton, Alberta. Laserdisc.

Wilson, C.C. 1977. Fatal and near-fatal forest fires - the common denominators. Int. Fire Chief 43(9): 9-10, 12-15. 